\title{
Does Institutions Effect Growth in Pakistan? An Empirical investigation
}

\author{
Dr. Danish Ahmed Siddiqui (Corresponding author) \\ Associate Professor, Karachi University Business School \\ Karachi University Business School, University of Karachi, Karachi, Pakistan \\ Tel: +92-333-348-5884_E-mail: daanish79@hotmail.com
}

Dr. Qazi Masood Ahmed

Professor and Director Research, Institute of Business Administration

Institute of Business Administration, Karachi., Pakistan

Tel: +92-300-235-2239Ｅ-mail: qmasood@iba.edu.pk

Received: Dec 10, 2018

Accepted: Dec 2, 2018

Published: January 3, 2019

doi:10.5296/jad.v5i2.13914

URL: https://doi.org/10.5296/jad.v5i2.13914

\begin{abstract}
This paper presents an index of institutionalized social technologies for Pakistan, covering its two main dimensions namely Risk reducing technologies and Anti Rent seeking technologies and in turn covers several social, institutional, political and economic aspects. It is also analyzed empirically whether the overall index as well as sub-indexes constructed to measure the single dimensions affects economic growth. The results show that over all, institutions promote growth in long run for Pakistan. Therefore, for a policy implication, success of any policy could be influenced by the soundness of institutions.
\end{abstract}

Keywords: Institutions, Growth, Pakistan, Rent Seeking, Index, Political Rents 


\section{Introduction}

Despite of the fact the role of institutions in shaping economic history has given significant importance but the empirical literature focusing on the concept of institutions is not adequate in social sciences (Note 1). The contributors to the voluminous descriptive literature on institutions are, (Baumol, 1996; Lane, 1984; North, 1991). They define institutions as the rules of the game in a society or, more formally, the humanly devised constraints that shape human interaction. These rules of the game can be in the form of formal institutions like laws and regulations or informal ones which assimilated to culture or social capital (Tabellini, 2010; Putnam, 1994). Some institutions lower transaction cost thereby result in innovation and productivity whereas other institutional features impedes information flow, raising information costs and eroding the gains from information, and limits the entrepreneurial activity. Examples of the institutions that stunt economic growth include government, police, court corruption, excessive taxation and regulation, unstable inconsistent monetary and fiscal policy (Frye, 1996; Johnson, 2000; Gwartney, 1998; Johnson, 1998; Shleifer, 1993; De Soto, 2000).

The relationship between economic performance and the quality of domestic institutions has emerged recently as a major subject of interest. The literature shows that the higher the quality of domestic institutions the better the effects on the Human development and growth of a country. The causality between institutions and economic performance is also important issue and studies shows better institutions leads to a higher income rather than causation being in the opposite direction. However most of the empirical evidence about the relationship between institutions and growth are based on cross-sectional and cross-country analysis. Quite apart from general methodological flaws relating to model specification and econometric procedure, there are two fundamental limitations that make results from any cross-country study on the subject rather dubious. First, cross-country regression analysis is based on the implicit assumption of homogeneity in the observed relationship across countries. This is very restrictive assumption. Secondly, given vast difference among countries with respect to nature and quality of data, cross-country comparison is fraught with danger. These considerations point a need for undertaking econometric analysis of individual countries over time in order to build a sound empirical foundation for informing the policy debate. Furthermore, no attempt to our knowledge has yet been made in this direction for Pakistan. This paper tries to contribute to the literature in examining the effects of several dimensions of institutions on growth empirically for Pakistan. Since many of these dimensions are highly correlated, it is impossible to include them all individually in one regression. Therefore, the paper develops an index covering its most important aspects. To measure these dimensions, 12 variables have been combined to two sub-indexes using an objective statistical method. The sub-indexes are in turn aggregated into one single index of institutions. Several other studies attempted to aggregate institutions but this aggregation is based on the institutions' relative importance in economic performance as their authors' sees it, this clearly lacks proper theoretical bases. In this study we tried to aggregate variables to judge Pakistan's institutional quality in a proper theoretical framework.

We take our queue from theoretical framework set by Douglass Cecil North (1981) who 
explains the roles of institutions, proposes two theories, a Contract theory of the state and a predatory theory of the state. Accordingly, in this study, we attempted to explore these roles through the notion of institutionalized social technologies. The term social technologies involve patterned human interaction rather than physical engineering, also has been put forth by (North, 1994 ;Boserup, 1996; Day, 1989). R. R. Nelson and Sampat (2001) proposed, not all social technologies are institutions, but rather only those that have become a standard and expected thing to do, given the objectives and the setting. Institutionalized social technologies define low transaction cost ways of doing things that involve human interaction. Hence in effectively institutionalized social technologies, individuals capture the social returns to their actions as private returns (North, 1973). It protects the output of individual productive units from diversion and also resolves the problem of asymmetric information as it develop mutual trust among agents. Whereas ineffective institutionalized social technology will not only increase the risk but also divert economic agents from innovative activities to seeking rents. Accordingly, our index of institutionalized social technologies is divided into Risk reducing technologies and Anti Rent seeking technologies.

Paper is organized as follows section 1 introduction, section 2 covers review of literature, section 3 covers methodology and rational for index, section 4 Empirical estimates, Section 5 Analysis and Results and Section 6 gives conclusions and recommendations.

\section{Review of Literature}

The Contract theory literature, starting with Coase (1960) and Williamson (1985), links the efficiency of organizations and societies to what type of contracts can be written and enforced, and thus underscores the importance of contracting institutions (Grossman, 1986; Hart, 1990; Hart, 1995). In contrast, other authors advocating predatory theory, emphasize the importance of private property rights, especially their protection against expropriation (see, among others, (Jones, 2003; De Long, 1993; Olson, 2000). Concept of institutions as social technologies is consonant with the notion that institutions are the rules of the game. R. R. Nelson and Sampat (2001) proposed that particular social technologies become institutionalized through different mechanisms and are sustained through different structures. Pelikan (2003), Institutionalized social technology are those rule routines (technology) that are imposed by society or government through laws, norms, expectations, governing structures and mechanisms, customary modes of transacting and interacting, and converted into rule constraints.

R. Nelson (2007) point out societies clearly have a degree of control over institutions like the formal structure of laws, and formal organizational designs and designated authority relationships. W. J. Baumol (1993) pointed out information asymmetry through rent seeking or organized crime is curbed through strong institutions so only venue left for competition and dominance is through innovation. Hence in the setting of effective enforcement, these asymmetries will lead to innovation as the only venue left to earn information rents.

First component in our index of institutional technologies is Risk reducing technologies. Increased risk diverts resources from productive activities to protecting their rights. Hall and Jones (1999) showed quantitatively, how important these effects are. Productive activities are vulnerable to predation. As they put it, Social control of diversion has two benefits. First, in a 
society free of diversion, productive units are rewarded by the full amount of their production, and where there is diversion, on the other hand, it acts like a tax on output. Second, where social control of diversion is effective, individual units do not need to invest resources in avoiding diversion. In many cases, social control is much cheaper than private avoidance. Social control act as a threat of punishment, which itself is free and the only resources required are those needed to make this threat credible. In other word social control does not means collectively hiring guards by society proves to be cheaper. Magee, Brock, and Young (1989) and Murphy, Shleifer, and Vishny (1991) explain how inadequate controls affect growth.

Second and perhaps more important measure of institutional quality is index of anti-rent seeking technologies. As shown earlier, the rent-seeking (behavior) refers to the socially costly pursuit of wealth transfers (Tollison, 1997). In other words, rent-seeking is manifested when the bottom-line of its social consequences is negative.

Mehlum and Moene (2003) explains the notion of destructive creations asserts that it all starts from the breakdown of institutions, generating new opportunities of extracting rents without producing. A vast literature can be found linking entrepreneurship, rent seeking and growth (Murphy, 1991; Baumol, 1996; Acemoglu, 1995; Acemoglu, 1998).

There is dearth of literature exploring relationship between institution and economic performance. In particular, D. Acemoglu, Johnson, and Robinson (2005) show that quality of institutions have a more important effect on long term growth than on short term one. Jalilian, Kirkpatrick, and Parker (2007) emphasizes the role of regulatory institutional capacity in accounting for cross country variations in economic growth Méon and Sekkat (2004) and Olson (2000) find evidence suggesting that institutional factors are strongly related to total factor productivity. As productivity growth is higher in countries with better institutions and quality of governance.

With regards to causal effect between institutions and economic performance, studies like D. Acemoglu, Johnson, and Robinson (2001); Olson et al. (2000); Rodrik, Subramanian, and Trebbi (2004); Kaufman, Kraay, and Mastruzzi (2005), indicates indicate that a better institutions leads to a higher income rather than causation being in the opposite direction. In particular Kauffman suggests that a one standard deviation improvement in governance institutions leads to a two to threefold difference in income levels in the long run.

D. Acemoglu et al. (2005) who attempted to distinguish between anti-rent seeking institutions and risk-reducing institutions, as they termed them as property rights and contracting institutions respectively. They found strong support for the importance of anti-rent seeking institutions on economic outcome but in contrast, indicate that the role of risk reducing institutions is more limited. The reason they give to this fact is, in absence of formal risk reducing institutions contracting institutions, the gap is filled by private alternative institutional arrangement. Like in earlier times when formal institutions of courts and police don't exist or ineffective, people then resort to dwell in groups where contracts are honored through informal pressure and risk of expulsion from group. Hence their rights are secured in other ways. In contrast, protection from rent seeking behavior relates to the relationship 
between the state and the citizens. When the states have major problems of corruption, inefficiency or no checks on the state, on politicians, and on elites, individuals don't have a level playing fields and adds to uncertainty. In this case, they are also unable to enter into private arrangements to circumvent these problems. In regional context, Fernandes, Kraay, and Bank (2007) employing firm level data found the similar evidence that firms in the South Asian countries are able to circumvent failures in formal "contracting institutions", by resorting frequently to informal channels such as belonging to a business association. Some studies find that the quality of governance and institutions is important in explaining the rates of investment, as they suggested they effect economic performance through improving the climate for capital creation (Kirkpatrick, 2006; Kaufman, 2005). Other studies reiterated institutional roles in improving international capital flows in particular FDI (Reisen, 2001; Javorcik, 2000) and portfolio investment (Gelos \& Wei, 2002).

A number of studies have made attempts to examine institutions in Pakistan as well in south Asian region. Mahbub-ul-Haque (1999) and Ahmed (2001) illustrated that institutions appears to be a significant problem in South Asia. Especially in Pakistan, institutional decay has led to poor governance, which has resulted in ad hoc policy-making. Instability and unpredictability has discouraged long-term investment and encouraged lobbying, corruption, and misuse of power, resulting in frustration and dysfunctional behavior. Asserts weak institutions have been used by elite to extract rents in Pakistan. Institutional impact on poverty is explored in Pakistan, which shows institutions are negatively and significantly correlated with poverty, hence weak institutions to increase in poverty in Pakistan. However in contrast to the popular notion, Studies like Shafique, Haq, and Arif (2006) based on World Bank's governance indicators, find weak institutions do improve welfare of the society but it has negative influence on GDP growth rate. At another place, Fernandes et al. (2007) and Easterly (2003) in a study suggest that Pakistan have per capita incomes that are considerably higher than their very weak institutional performance would suggest based on average cross-country relationships. The similar assessment in the context of political institutions in made by SPDC (Ismail, Rizvi, \& Mahmood, 2000), which shows that while governments under authoritarian rule in Pakistan were good for economic growth, they were not necessarily as successful in improving human endowment. Authoritarian rule normally associated of weak institutions whereas vice versa for democracy.

\section{Methodology and Rational of Index}

In this section we focus on index description, data sources, Normalization procedure and lastly weighting and aggregation methodology.

\subsection{Description of Indices}

In this section we define the computation of the following indices.

\subsubsection{Index of Institutionalized Social Technologies (sci)}

Technologies consist of those factors that increase efficiency and productivity. This index measures technologies that are bundle of information that consists of routines and processes imposed by society, which creates positive rents in the economy. These rents are pareto 
improving and results in Schumpeterian creative destruction, whereas improperly enforced institutional technology creates negative rents doesn't result in increasing return to scale at economy level, but results in mere redistribution of wealth within the economy creating inequality. This is an aggregate cross national index that encompasses the impact of all institutional performance indicators and comprises of Index of Risk Reducing Technologies and the Index of Anti Rent seeking Technologies. (See Table 1).

Table 1. Components of Index of Institutionalized Social Technology (IIST)

\begin{tabular}{lllll}
\hline A & Ri & Index of Anti Rent Seeking Technology & $\mathbf{0 . 5}$ \\
\hline 1 & RiB & Bureaucracy Quality & 0.18 \\
2 & RicC & Corruption & 0.07 \\
3 & RpA & Democratic Accountability & 0.16 \\
4 & RpP1 & Executive recruitment & 0.15 \\
5 & RpP2 & Political competition & 0.16 \\
& 6 & RpR & Political rights & 0.11 \\
7 & RpV & Civil liberties & 0.17 \\
\hline B & Sii & Index of Risk Reducing Technologies & $\mathbf{0 . 5}$ \\
\hline 1 & SicC1 & Investment Profile & 0.26 \\
& 2 & SilL1 & Law and Order & 0.17 \\
3 & SilL2 & Torture, Extrajudicial Killing, Political Imprisonment, and Disappearance indicators & 0.16 \\
4 & SisG & Government Stability & 0.23 \\
& 5 & SisB & Executive constraints & 0.18 \\
\hline
\end{tabular}

\subsubsection{Index of Risk Reducing Technologies (Sii)}

First component of institutionalized social technology is called risk reducing technology. It measures institutional arrangements that reduce transactional risk. Risk is an important component of business decisions which requires long term transactions, which require transactional trust. Well enforced Risk reducing technologies strengthen this transactional trust. The absence of transactional trust advantages individuals who can overcome the resulting institutional deficiencies. For example, a biased or ineffective justice system makes property rights insecure for all except those who have power to secure it privately. As a result, returns to investment for those people would be considerably more than the rest who bears higher risk due to insecurity. As a result, it will divert individuals and businesses from innovative activities to become predictive rent seekers.

Moreover, increased risk diverts resources from productive activities to protecting their rights. As a result, it lowers productivity. Rephrasing a bookish example, if a farm cannot be 
protected from theft, then thievery will be an attractive alternative to farming. A fraction of the labor force will be employed as thieves, making no contribution to output. Farmers will spend more of their time and resources protecting their farms from thieves like they must hire guards and put up fences and consequently grow fewer crops from available resources. In short Risk Reducing technology removes information asymmetry, creates mutual trust and hence decreases the risk of creating long term business relationships. This intern increase productivity and growth.

Index of risk reducing technologies is aggregate form of following variables

(1) Investment profile majoring Contract Viability/Expropriation, Profits Repatriation, and Payment Delays.

(2) Law and Order.

(3) Torture, Extrajudicial Killing, Political Imprisonment, and Disappearance indicators.

(4) Government Stability.

(5) Executive constraints.

There weights in risk reducing technology index are $26 \%, 17 \%, 16 \%, 23 \%$, and $18 \%$ respectively.

\subsubsection{Index of Anti-Rent Seeking Technologies (Ri)}

Predatory rents can be gained through weak institutionalization of risk reducing technologies as explained earlier. However, this component exclusively focuses on those rents seeking opportunities that arise due to loopholes in ineffective or week institutions. Rent-seeking is defined as a situation in which an individual or firm makes money by manipulating economic environment rather than by profit making through innovation. Gaps in institutions create rents for controlling agents betting them higher return then though innovation hence society moves from innovative to rent seeking activities. Rent extraction is a strategic substitute for productive activities as improved opportunities of rent extraction leads to higher profits to parasites on the expense of the producers, in short run it will hamper productive investments but in the longer run the profit differential induces a reallocation of entrepreneurs away from production. As production declines and congestion among parasites sets in, both parasites and producers lose profits (Usher, 1987). In other words, while more efficient producers raise income both for producers and parasites, more efficient parasites lower the income for both. In short rent seeking does produce rents for predicators but their impact in economy is zero or negative, since resources are not used in increasing the size of the economic pie, but diverted to snatching the bigger piece from others. Specifically, this index focuses on technologies which helps eliminate three kinds of rent accordingly, it is subdivided into the following components.

(1) Bureaucracy Quality

(2) Corruption 
(3) Democratic Accountability

(4) Executive recruitment

(5) Political competition

(6) Political rights and

(7) Civil liberties.

Their weights in Index are $18 \%, 7 \%, 16 \%, 15 \%, 16 \%, 11 \%, 17 \%$ respectively. Description of index of institutionalized social technology and its subcomponents are provided in Table 1.

\subsection{Data Sources and Description}

Variables used in construction of indices are taken from various data sources. Most prominent is Political risk service's international country risk guide. Since January 1984, the ICRG has been compiling economic, financial, political and composite risk ratings for 90 countries on a monthly basis. The ICRG rating system comprises 22 variables, representing three major components of country risk, namely economic, financial and political. We included 6 variables mostly measuring political risk in creation of our index. As this data is on monthly basis, we use 12-month average to convert to annual frequency. Three variables of political nature are taken from POLITY 4 project managed by Center for Systemic Peace. Its data is of annual frequency available since 1975 and has become the most widely used data resource for studying regime change and the effects of regime authority. Data of political rights and civil liberties are taken from Freedom of the world index, published by Freedom house published annually since 1955. The variable of Torture, Extrajudicial Killing, Political Imprisonment, and Disappearance indicators is taken from Physical integrity index composed by Cingranelli-Richards (CIRI) Human Rights Dataset containing human rights data for 195 countries, annually from 1981. Description of variables used in index are included in Table 2.

\subsection{Normalization Procedure}

Because of different measuring scales used in different variables, to include them in index, we use normalization treatment thereby converting each variable to an index with a zero to one scale, where higher values denote more strong institutions. When higher values of the original variable indicate weak institutions (like country ranks), the formula $(\mathrm{Vmax} V \mathrm{~V}) /(\mathrm{Vmax}-\mathrm{Vmin})$ is used for transformation. Conversely, when higher values indicate strong institutions, the formula $(\mathrm{Vi}-\mathrm{Vmin}) /(\mathrm{Vmax}-\mathrm{Vmin})$ is used. Here $\mathrm{Vi}=$ original values, $\mathrm{V} \max =$ Maximum value attained by country in original index, Vmin $=$ Minimum value attained by country in original index. Similar strategy is being employed in creation of various indices notably (Gwartney, 2008; Miller, 2015; Schwab, 2008),. Descriptive statistics of these variables are provided in Table 3. 
Table 2. Index composition and data description

\begin{tabular}{|c|c|c|c|c|c|}
\hline Name & Abbreviation & $\begin{array}{l}\text { Parent } \\
\text { index }\end{array}$ & $\begin{array}{l}\text { Theoretical } \\
\text { Ranges }\end{array}$ & Source & Type \\
\hline $\begin{array}{l}\text { Bureaucracy } \\
\text { Quality }\end{array}$ & $\mathrm{RiB}$ & \multirow{6}{*}{ 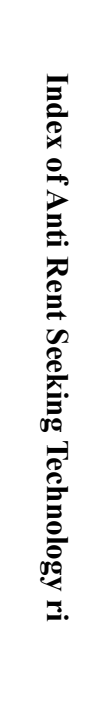 } & $1-4+$ & \multirow{3}{*}{$\begin{array}{l}\text { International Country Risk } \\
\text { Guide(ICRG) -Political Risk } \\
\text { Services(PRS), New York } \\
<\text { www.prsgroup.com> }\end{array}$} & \multirow{3}{*}{$\begin{array}{l}\text { Expert } \\
\text { assessments } \\
\text { subject to peer } \\
\text { review at } \\
\text { the topic and } \\
\text { regional } \\
\text { levels }\end{array}$} \\
\hline Corruption & RicC & & $1-6+$ & & \\
\hline $\begin{array}{l}\text { Democratic } \\
\text { Accountability }\end{array}$ & RpA & & $1-6+$ & & \\
\hline $\begin{array}{l}\text { executive } \\
\text { recruitment }\end{array}$ & $\mathrm{RpP} 1$ & & $1-8-+$ & \multirow{2}{*}{$\begin{array}{l}\text { Marshall Monty G., Jaggers Keith." } \\
\text { POLITY IV PROJECT", Center for } \\
\text { Systemic Peace, } \\
\text { <www.systemicpeace.org/polity> }\end{array}$} & \\
\hline $\begin{array}{l}\text { political } \\
\text { competition }\end{array}$ & RpP2 & & $1-10-+$ & & \\
\hline political rights & $\mathrm{RpR}$ & & $1-7--$ & $\begin{array}{l}\text { Freedom in the World (various } \\
\text { editions), Freedom House, New York }\end{array}$ & \\
\hline civil liberties & $\mathrm{RpV}$ & & 1-7-- & $<$ http://www.freedomhouse $>$ & \\
\hline Investment Profile & $\mathrm{SicC} 1$ & \multirow{5}{*}{ 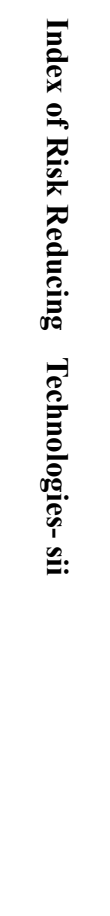 } & $1-12+$ & \multirow{3}{*}{$\begin{array}{l}\text { International Country Risk } \\
\text { Guide(ICRG) -Political Risk } \\
\text { Services(PRS), Network } \\
<\text { www.prsgroup.com> }\end{array}$} & \multirow{3}{*}{$\begin{array}{l}\text { Expert } \\
\text { assessments } \\
\text { subject to peer } \\
\text { review at } \\
\text { the topic and } \\
\text { regional } \\
\text { levels }\end{array}$} \\
\hline Law and Order & SilL1 & & $1-6+$ & & \\
\hline $\begin{array}{l}\text { Government } \\
\text { Stability }\end{array}$ & SisG & & $1-12+$ & & \\
\hline $\begin{array}{l}\text { Torture, } \\
\text { Extrajudicial } \\
\text { Killing, Political } \\
\text { Imprisonment, and } \\
\text { Disappearance } \\
\text { indicators }\end{array}$ & SilL2 & & $0-8-+$ & $\begin{array}{l}\text { CINGRANELLI DAVID L., RICHARDS } \\
\text { DAVID } \quad \text { L., } \\
\text { CIINGRANELLIIRIICHARDS } \\
\text { HUMAN RIIGHTS } \\
\text { (CIIRII) } \\
\text { DATA PROJECT } \\
<\text { http://www.humanrightsdata.org/> }\end{array}$ & \\
\hline $\begin{array}{l}\text { executive } \\
\text { constraints }\end{array}$ & SisB & & $1-7-+$ & $\begin{array}{l}\text { Marshall Monty G., Jaggers Keith." } \\
\text { POLITY IV PROJECT”, Center for } \\
\text { Systemic Peace, } \\
\text { <www.systemicpeace.org/polity> }\end{array}$ & \\
\hline
\end{tabular}

\subsection{Weighting and Aggregation Methodology}

Principal component analysis is used to determine the weight given to each component in the construction of the index. This procedure partitions the variance of a set of variables and uses it to determine the linear combination the weights of these variables that maximizes the variation of the newly constructed principal component. In effect, the newly constructed principal component is the variable that captures the variation of the underlying components most fully. It is an objective method of combining a set of variables into a single variable that 
best reflects the original data. As J. D. Gwartney and Lawson (2001) point out, this procedure is particularly appropriate when several sub-components measure different aspects of a principal component. The component weights derived by this procedure are shown in parentheses in Figure 1. The same procedure was also used to derive the weights for the sub-indices that are used in the construction of main indices referred in Figure1.

Table 3. Descriptive statistics of variables used in index.

\begin{tabular}{lll}
\hline Variables Abb. & Mean & Std. Deviation \\
\hline RiB & 0.95652 & 0.20851 \\
RicC & 0.47464 & 0.22074 \\
RpA & 0.39529 & 0.25862 \\
RpP1 & 0.43478 & 0.43444 \\
RpP2 & 0.55797 & 0.43406 \\
RpR & 0.58696 & 0.34219 \\
RpV & 0.10870 & 0.29987 \\
SicC1 & 0.47467 & 0.22523 \\
SilL1 & 0.51742 & 0.26748 \\
SilL2 & 0.44348 & 0.25553 \\
SisG & 0.60039 & 0.28968 \\
SisB & 0.54348 & 0.42999 \\
\hline
\end{tabular}

Table 4. Factor extraction and rotation based on principal component analysis

\begin{tabular}{|c|c|c|c|c|c|c|c|c|}
\hline \multirow{2}{*}{$\begin{array}{l}\text { S. } \\
\text { No. }\end{array}$} & \multirow{2}{*}{ Indices } & \multirow{2}{*}{$\begin{array}{l}\text { Extracted } \\
\text { Factors }\end{array}$} & \multicolumn{3}{|c|}{ Extraction Sums of Squared Loadings } & \multicolumn{3}{|c|}{ Rotation Sums of Squared Loadings } \\
\hline & & & $\begin{array}{l}\text { Eigen } \\
\text { values }\end{array}$ & $\begin{array}{l}\% \\
\text { Variance }\end{array}$ & Cumulative \% & $\begin{array}{l}\text { Eigen } \\
\text { values }\end{array}$ & $\begin{array}{l}\% \\
\text { Variance }\end{array}$ & Cumulative \% \\
\hline \multirow{3}{*}{1} & \multirow{3}{*}{$\mathrm{Ri}$} & 1 & 3.967145474 & 56.67350678 & 56.67350678 & 3.31815758 & 47.40225114 & 47.40225114 \\
\hline & & 2 & 1.182852284 & 16.89788977 & 73.57139654 & 1.384364119 & 19.77663027 & 67.17888141 \\
\hline & & 3 & 0.931173398 & 13.30247712 & 86.87387366 & 1.378649458 & 19.69499225 & 86.87387366 \\
\hline \multirow{2}{*}{2} & \multirow{2}{*}{ sii } & 1 & 2.608787128 & 52.17574257 & 52.17574257 & 2.49698881 & 49.9397762 & 49.9397762 \\
\hline & & 2 & 1.057745676 & 21.15491353 & 73.33065609 & 1.169543995 & 23.39087989 & 73.33065609 \\
\hline 3 & iist & 1 & 1.448818986 & 72.44094932 & 72.44094932 & & & \\
\hline
\end{tabular}


More specifically first, principal components analysis is used to extract factors (Manly \& Hall, 1994). We choose factors that fulfil these considerations:

(i) Have associated eigenvalues larger than one;

(ii) Contribute individually to the explanation of overall variance by more than $10 \%$;

(iii) Contribute cumulatively to the explanation of the overall variance by more than $60 \%$.

Table 5. Extracted factor loadings and weights

\begin{tabular}{|c|c|c|c|c|c|c|c|c|c|c|c|}
\hline \multirow[t]{2}{*}{ Indices } & \multirow[t]{2}{*}{ Components } & \multicolumn{2}{|c|}{$\begin{array}{l}\text { Rotated } \\
\text { loadings }\end{array}$} & \multicolumn{3}{|c|}{$\begin{array}{r}\text { FactorSquared } \\
\text { loadings }\end{array}$} & \multicolumn{3}{|c|}{$\begin{array}{c}\text { FactorSquared Factor } \\
\text { (Scaled to unity) }\end{array}$} & loadings & \multirow[t]{2}{*}{$\begin{array}{c}\text { Weights } \\
\text { Weight(Scaled } \\
\text { unity) }\end{array}$} \\
\hline & & 1 & 2 & 3 & 1 & 2 & 3 & 1 & 2 & 3 & \\
\hline \multirow{9}{*}{$1 \mathbf{R i}$} & RiB & 0.0873 & 0.1153 & 0.9560 & 0.0076 & 0.0133 & 0.9140 & 0.0023 & 0.0096 & 0.6630 & 0.15030 .18 \\
\hline & $\mathrm{RicC}$ & 0.6012 & -0.1958 & 0.5878 & 0.3614 & 0.0383 & 0.3455 & 0.1089 & 0.0277 & 0.2506 & 0.05680 .07 \\
\hline & $\mathrm{RpA}$ & 0.9045 & -0.2039 & 0.0882 & 0.8181 & 0.0416 & 0.0078 & 0.2465 & 0.0300 & 0.0056 & 0.13450 .16 \\
\hline & RpP1 & -0.8848 & $8-0.3695$ & -0.1316 & 60.7829 & 0.1365 & 0.0173 & 0.2359 & 0.0986 & 0.0126 & 0.12870 .16 \\
\hline & $\mathrm{RpP} 2$ & 0.8873 & 0.3498 & 0.1517 & 0.7873 & 0.1223 & 0.0230 & 0.2373 & 0.0884 & 0.0167 & 0.12950 .16 \\
\hline & $\mathrm{RpR}$ & 0.7389 & 0.4392 & 0.2661 & 0.5459 & 0.1929 & 0.0708 & 0.1645 & 0.1393 & 0.0514 & 0.08980 .11 \\
\hline & $\mathrm{RpV}$ & 0.1219 & 0.9162 & 0.0165 & 0.0149 & 0.8394 & 0.0003 & 0.0045 & 0.6063 & 0.0002 & 0.13800 .17 \\
\hline & Sum & & & & 3.3182 & 1.3844 & 1.3786 & & & & 0.8277 \\
\hline & weights & & & & 0.5456 & 0.2276 & 0.2267 & & & & \\
\hline \multirow{7}{*}{2 sii } & $\mathrm{SicC} 1$ & -0.0155 & 50.9332 & & 0.0002 & 0.8709 & & 0.0001 & 0.7446 & & 0.23750 .26 \\
\hline & SilL1 & 0.7634 & 0.4543 & & 0.5827 & 0.2064 & & 0.2334 & 0.1765 & & 0.15890 .17 \\
\hline & SilL2 & -0.7357 & 70.1060 & & 0.5413 & 0.0112 & & 0.2168 & 0.0096 & & 0.14760 .16 \\
\hline & SisG & 0.8817 & 0.2626 & & 0.7775 & 0.0690 & & 0.3114 & 0.0590 & & 0.21200 .23 \\
\hline & SisB & -0.7715 & 50.1099 & & 0.5952 & 0.0121 & & 0.2384 & 0.0103 & & 0.16230 .18 \\
\hline & Sum & & & & 2.4970 & 1.1695 & & & & & 0.9185 \\
\hline & weights & & & & 0.6810 & 0.3190 & & & & & \\
\hline \multirow{3}{*}{3 iist } & ri & 0.8511 & & & 0.7244 & & & & & & 0.5000 \\
\hline & sii & 0.8511 & & & 0.7244 & & & & & & 0.5000 \\
\hline & weights & & & & 1.4488 & & & & & & \\
\hline
\end{tabular}

Details of extracted factors are provided in Table 4. These factors are then rotated in order to minimize the number of individual indicators that have a high loading on the same factor. The idea behind transforming the factorial axes is to obtain a simpler structure of the factors. Rotation is a standard step in factor analysis. It changes the factor loadings and hence the interpretation of the factors, while leaving unchanged the analytical solutions obtained ex-ante and ex-post the rotation. Weights are then calculated through the square of factor loadings after rotation which represents the proportion of the total unit variance of the 
indicator which is explained by the factor. Similar approach is used by Nicoletti, Scarpetta, and Boylaud (1999) that is of grouping the individual components with the highest factors loadings into intermediate Factor. These Factors aggregated by assigning a weight to each one of them equal to the proportion of the explained variance in the data set. The components of extracted and rotated factors along with component weights are given in Table 5.

For Aggregation, we employ linear aggregation which is the summation of weighted and normalized individual indicators. Table 6 shows the results for the index of institutionalized social technologies as well as its sub-indices of Pakistan for the period 1984 to 2006.

Table 6. The Index of Institutionalized Social Technology and its sub-indices

\begin{tabular}{|c|c|c|c|}
\hline \multirow{2}{*}{ Obs. } & \multirow{2}{*}{ IIST } & \multicolumn{2}{|r|}{ IIST } \\
\hline & & RI & SII \\
\hline 1984 & 0.2741 & 0.1820 & 0.3662 \\
\hline 1985 & 0.5128 & 0.4687 & 0.5569 \\
\hline 1986 & 0.5330 & 0.4980 & 0.5679 \\
\hline 1987 & 0.5081 & 0.5007 & 0.5154 \\
\hline 1988 & 0.6487 & 0.7190 & 0.5785 \\
\hline 1989 & 0.6112 & 0.7190 & 0.5034 \\
\hline 1990 & 0.4609 & 0.6065 & 0.3152 \\
\hline 1991 & 0.4524 & 0.5215 & 0.3833 \\
\hline 1992 & 0.4906 & 0.5215 & 0.4597 \\
\hline 1993 & 0.4969 & 0.5490 & 0.4448 \\
\hline 1994 & 0.5920 & 0.5970 & 0.5870 \\
\hline 1995 & 0.5951 & 0.6130 & 0.5772 \\
\hline 1996 & 0.6678 & 0.5935 & 0.7421 \\
\hline 1997 & 0.7395 & 0.6496 & 0.8294 \\
\hline 1998 & 0.6476 & 0.5885 & 0.7067 \\
\hline 1999 & 0.4658 & 0.4972 & 0.4345 \\
\hline 2000 & 0.3989 & 0.4192 & 0.3786 \\
\hline 2001 & 0.4535 & 0.4163 & 0.4908 \\
\hline 2002 & 0.4601 & 0.3975 & 0.5226 \\
\hline 2003 & 0.4273 & 0.3962 & 0.4585 \\
\hline 2004 & 0.4204 & 0.3962 & 0.4447 \\
\hline 2005 & 0.4420 & 0.3962 & 0.4879 \\
\hline 2006 & 0.4822 & 0.3962 & 0.5683 \\
\hline
\end{tabular}




\section{Empirical Analysis}

The aim of the empirical section of the paper is to investigate links between nations' institutional quality and economic growth, using OLS as well as GMM instrumental variable estimation method in order to control for endogeneity. This subsection describes data, the regression specifications and methodology.

\subsection{Data Description}

The dependent variable is the Real GDP per capita in real term. There are two sets of independent variables. First is the institutional variables and send being control variables. We take index of institutionalized social technology, as well as its sub-indices of Risk reducing technologies and Anti-rent seeking technologies for measurement of institutional quality.

Dependent and control variable such as total trade are taken from (Heston, Summers, Aten, \& Change, 2009). whereas other control variables such as Gross domestic savings and Inflation, are taken from World Development Indicators. Table 7 gives detailed information about the variables and their data source.

Table 7. Estimation variables' data sources and description

\begin{tabular}{|c|c|c|c|c|}
\hline & $\begin{array}{l}\text { Variable } \\
\text { Name }\end{array}$ & Description & & Source \\
\hline 1 & RGDPPC & Real GDP per capita at constant price (Laspeyres) & Initial Factor & $\begin{array}{l}\text { Heston and Summers } \\
\text { (2009) }\end{array}$ \\
\hline 2 & SAVGD & Gross domestic savings ( $\%$ of GDP) & Savings & $\begin{array}{l}\text { World Development } \\
\text { Indicators, World Bank }\end{array}$ \\
\hline 3 & INFCPI & Inflation, consumer prices (annual \%) & $\begin{array}{l}\text { Macroeconomic } \\
\text { Stability }\end{array}$ & $\begin{array}{l}\text { World Development } \\
\text { Indicators, World Bank }\end{array}$ \\
\hline 4 & OPEN & $\begin{array}{l}\text { Total trade (Exports plus Imports) as a percentage } \\
\text { of GDP. (export, import and GDP figures are } \\
\text { expressed in real values) }\end{array}$ & Openness & $\begin{array}{l}\text { Heston and Summers } \\
\text { (2009) }\end{array}$ \\
\hline 5 & IIST & Index Institutionalized Social Technologies & Institutions & $\begin{array}{l}\text { Authors' } \\
\text { calculations }\end{array}$ \\
\hline 6 & Sii & Aggregate Index of Risk reducing Technologies & Institutions & $\begin{array}{l}\text { Authors' } \\
\text { calculations }\end{array}$ \\
\hline 7 & $\mathrm{Ri}$ & Index of Anti-Rent seeking Technologies & Institutions & $\begin{array}{l}\text { Authors' } \\
\text { calculations }\end{array}$ \\
\hline
\end{tabular}

\subsection{Regression Specification}

The role of institutions quality in economic performance, is explained by north in contract theory and a predatory theory of the state. To assess these roles, we used standard growth 
regression framework which mostly follow growth empirics' literature, such as (Barro, 1991; Mankiw, 1992; Levine, 1992).

$$
Y t=\beta 0+\beta 1 \mathrm{It}+\beta 2 \mathrm{Xt}+\epsilon \mathrm{i}
$$

Where $t$ is time period $\epsilon t$ is the error term. The economic growth yt is measured by GDP per capita in real terms, it stands for institutional variables, whereas $\mathrm{Xt}$ is the vector of control variables for other determinants of growth.

Other determinants of growth denoted by Xt include variables to control for other factors that influence growth. In most empirical studies, the choices of additional control variables are ad hoc across studies. As one example, the data appendix in Levine and Renelt (1992) lists over 50 possibilities. In our study, we will be using variables pertaining to macroeconomic stability, savings and Openness. Macroeconomic stability factor in growth empirics is normally captured by consumer price inflation. It is expected that higher inflation tends to reduce growth due to a high level of price instability hence could have a negative expected sign. As Kormendi and Meguire (1985) and Grier and Tullock (1989) find that inflation are negatively related to growth. Saving represented by gross domestic saving as \% of GDP, is considered a crucial variable of growth equation. With positive expected sign, higher saving leads to higher investment which in turn leads to higher economic growth. The presumption is that higher saving precedes economic growth. In a typical model of economic growth such as the Solow (1956) model, a clear connection is made between saving and economic growth. Romer (1989) suggests that saving has too large an influence on growth and take this to be evidence for positive externalities from capital accumulation. On the empirical fount, Maddison (1992); Carroll and Weil (1994); Modigliani (1970) and Modigliani (1990) prove robust positive correlation between saving and growth. Another important variable included in our model is trade liberalization. Removal of trade restrictions helps to stabilize the development process by improving efficiency and return economies from distorted factor prices to production frontiers. Moreover, trade openness will improve domestic technology, production process will be more efficient, and hence productivity will rise (Jin \& Development, 2000). Trade liberalization and growth relations may occur through investment, and trade openness may provide greater access to investment goods (Levine \& Renelt, 1992). Countries that liberalize their external sector and reduce impediments to international trade can experience relatively higher economic growth. It is generally agreed that an open trade regime is crucial for economic growth and development (Ramakrishna, 2002). Descriptive Statistics of variables used in empirical analysis are shown in Table 8. 
Table 8. Descriptive statistics

\begin{tabular}{llllllll}
\hline & RGDPPC & IIST & RI & SII & WSAVGD & WINFCPI & OPEN \\
\hline Mean & 2619.487 & 0.5122 & 0.5062 & 0.5182 & 13.7610 & 7.4730 & 30.0948 \\
Median & 2632.580 & 0.4906 & 0.5007 & 0.5034 & 14.6839 & 7.8443 & 29.5600 \\
Maximum & 3388.570 & 0.7395 & 0.7190 & 0.8294 & 17.6117 & 12.3682 & 38.6100 \\
Minimum & 2058.170 & 0.2741 & 0.1820 & 0.3152 & 5.9293 & 2.9141 & 26.3000 \\
Std. Dev. & 335.2862 & 0.1050 & 0.1243 & 0.1224 & 3.5298 & 3.1318 & 3.1742 \\
Skewness & 0.5038 & 0.2035 & -0.3773 & 0.7651 & -0.8793 & 0.0319 & 1.1306 \\
Kurtosis & 3.0544 & 3.0077 & 3.3453 & 3.4498 & 2.6478 & 1.7241 & 3.8064 \\
Arque-Bera & 0.9759 & 0.1589 & 0.6599 & 2.4378 & 3.0824 & 1.5639 & 5.5235 \\
Probability & 0.6139 & 0.9236 & 0.7189 & 0.2955 & 0.2141 & 0.4575 & 0.0632 \\
Sum & 60248.1900 & 11.7809 & 11.6422 & 11.9197 & 316.5022 & 171.8781 & 692.1800 \\
Sum Sq. Dev. & 2473170 & 0.2426 & 0.3401 & 0.3296 & 274.1078 & 215.7741 & 221.6568 \\
Observations & 23.0000 & 23.0000 & 23.0000 & 23.0000 & 23.0000 & 23.0000 & 23.0000 \\
\hline
\end{tabular}

\subsection{Estimation Methodology}

We will be using OLS as well as GMM procedure in our analysis as there might be the problem of endogenity that could arise in independent variables specifically in institutional variables, as these variables have a strong positive correlation with growth. In literature, depending on the context, GMM has been applied to time series, cross-sectional, and panel data. Inevitably, GMM builds from earlier work, and its most obvious statistical antecedents are method of moments Pearson (1895) and instrumental variables estimation (Hansen \& Singleton, 1982; Reiersøl, 1941; Sargan, 1958). The starting point of GMM estimation is a theoretical relation that the parameters should satisfy that is to choose the parameter estimates so that the theoretical relation is satisfied as closely as possible. The GMM is a robust estimator in that, unlike maximum likelihood estimation, it does not require information of the exact distribution of the disturbances. The theoretical relation that the parameters should satisfy are usually orthogonality conditions between some (possibly nonlinear) function of the parameters $f(\theta)$ and a set of instrumental variables $\mathrm{zt}$ :

$$
\mathrm{E}\left(f(\theta)^{\prime} \mathrm{Z}\right)=0
$$

Where $\theta$ are the parameters to be estimated. The GMM estimator selects parameter estimates so that the sample correlations between the instruments and the function $f$ are as close to zero as possible, as defined by the criterion function:

$$
\mathrm{J}(\theta)=(\mathrm{m}(\theta))^{\prime} \mathrm{Am}(\theta)
$$

Where $\mathrm{m}(\theta)=f(\theta)^{\prime} \mathrm{Z}$ and $\mathrm{A}$ is a weighting matrix. Any symmetric positive definite matrix $\mathrm{A}$ will yield a consistent estimate of q. However, it can be shown that a necessary (but not sufficient) condition to obtain an (asymptotically) efficient estimate is to set A equal to the 
inverse of the covariance matrix of the sample moments $\mathrm{m}$.

To apply this methodology, the following equation is estimated by GMM:

$$
\Delta y \mathrm{i}=\beta 0+\beta 1 \mathrm{Ii}+\beta 2 \mathrm{Xi}+\epsilon \mathrm{i}
$$

The instrumental variables for the equation are twice lags of dependent variable and first lag of all explanatory variables.

\section{Results and Analysis}

Table 9. Average periodic trend

\begin{tabular}{llllllll}
\hline Period & RGDPPC & IIST & RI & SII & SAVGD & INFCPI & OPEN \\
\hline $1984-87$ & 2163.990 & 0.457 & 0.412 & 0.502 & 8.005 & 4.972 & 26.793 \\
$1988-91$ & 2418.430 & 0.543 & 0.642 & 0.445 & 12.387 & 9.381 & 29.273 \\
$1992-95$ & 2574.730 & 0.544 & 0.570 & 0.517 & 16.092 & 11.049 & 30.325 \\
$1996-99$ & 2680.893 & 0.630 & 0.582 & 0.678 & 14.581 & 8.030 & 28.135 \\
$2000-03$ & 2788.538 & 0.435 & 0.407 & 0.463 & 16.442 & 3.430 & 31.013 \\
$2004-06$ & 3247.290 & 0.448 & 0.396 & 0.500 & 15.492 & 8.143 & 36.677 \\
\hline
\end{tabular}

Table 1 focuses on periodic trends in institutional quality and growth. Over all institutional indicators fairly remain stable. They witness stable increase in periods of 1984 to 1999. Especially 1996-99 periods witnessed sharp increase in institutional quality. But afterwards, institutional index saw a sharp decline but again saw some improvements in later periods. On the political front, democratic era of 1988 to1999 saw a considerably higher institutional quality index then era govern by military dictatorships. Era of Transition to civilian democracy in 1988 witnessed sharp increase of about 19\% in institutional quality especially anti-rent seeking technologies increases by about 55\%, while Era followed by military takeover after 1999 saw a sharp decline of about $31 \%$ in institutional quality. This trend can also be witnessed from Figure 1. Hence strong political institutions do produce a huge impact of other social institutions in the country and reforming and strengthening the political institutions become pivotal in economic and social development. On the other hand, growth in economy measured by real GDP per capita, witnessed a stable increase over the years. However, comparatively higher growth was witnessed in era of 1984-91. In era of 90s, income level became fairly stable, and it sharply picked up later in 2000-06 period (Figure 2). Among other variables, savings remain fairly stable at about $15 \%$. Inflation followed income, remained started a bit higher, remains lower throughout the middle are witnessed a surge in 2003 onwards as economic witnessed a shape growth. Trade openness also witnessed a stable increase and picked up momentum after 2002 as policies towards liberalization took their ground. 


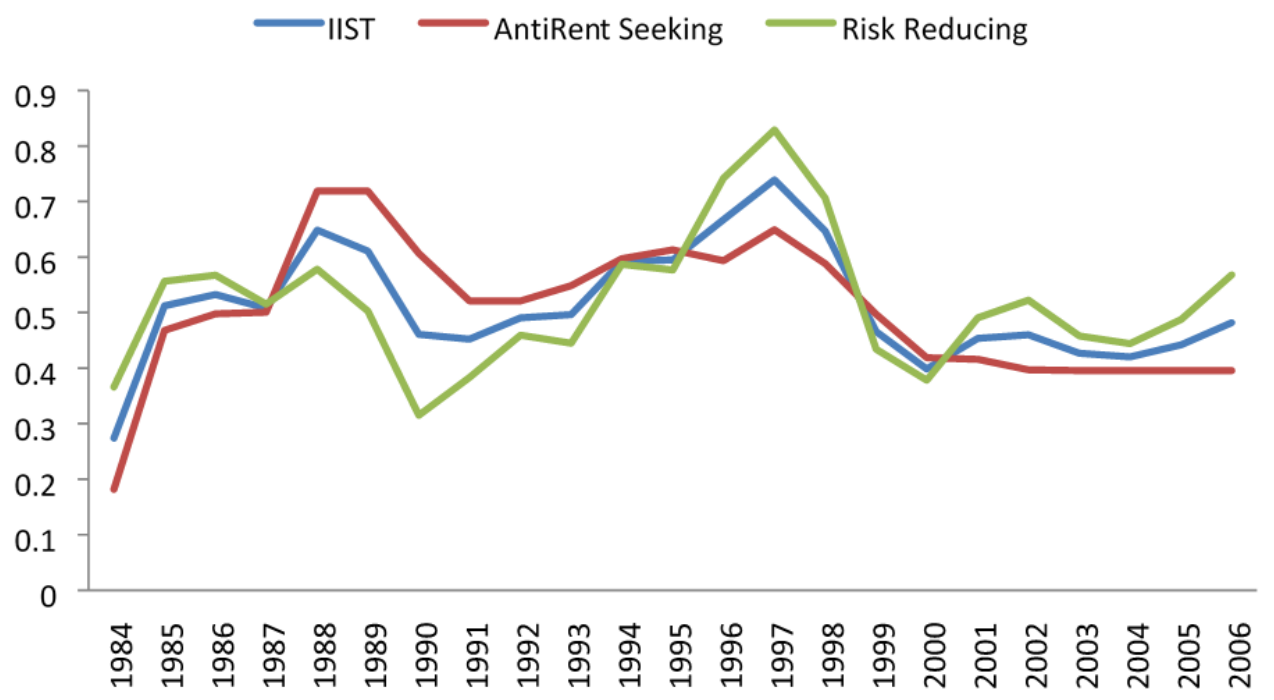

Figure 1. Institutionalized Social Technologies

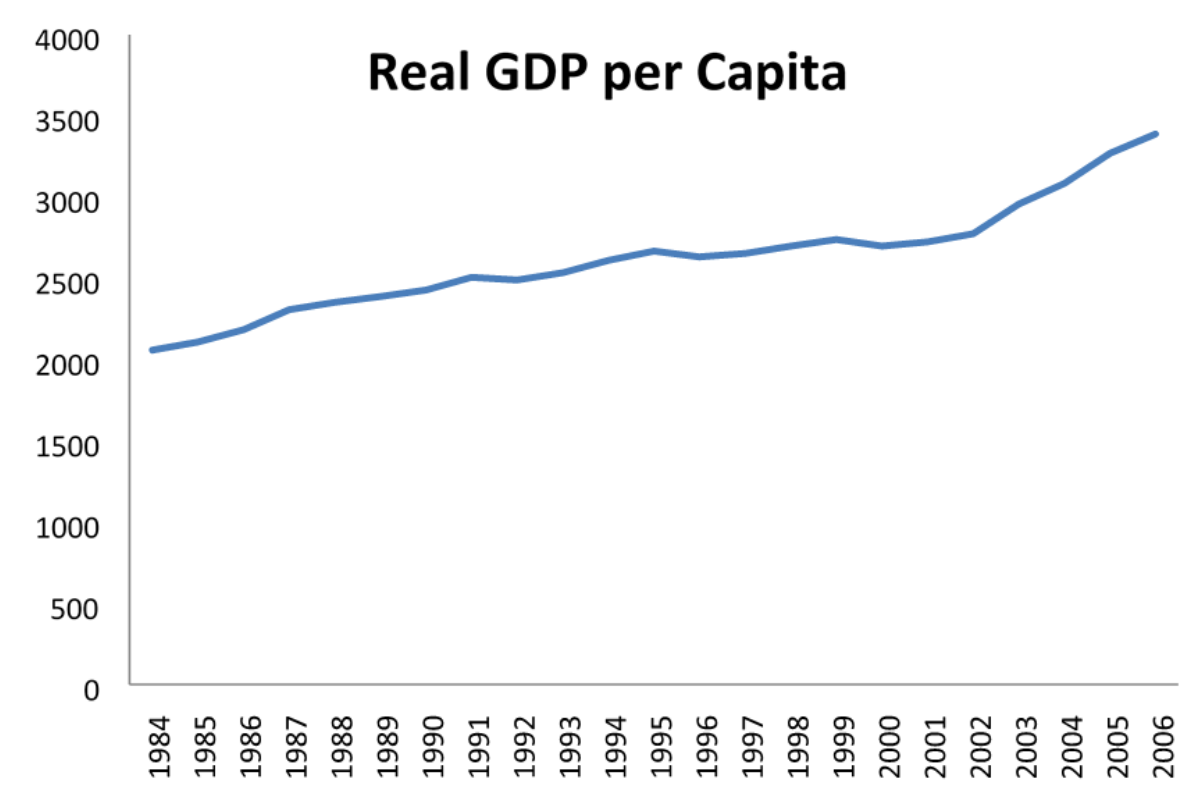

Figure 2. Real GDP per Capita

There are quite a few studies that found inverse link between institution and GDP growth. In a simulation to investigate this link, we regress GDP growth with our index, we found negative significant sign for institutions backing the previous studies, then we employ regression using GDP per capita as a proxy of growth, in our estimation procedure, we employ both OLS and GMM methodology. The estimation results clearly indicate a robust positive impact of institutional variables on growth (Table 10) 
Table 10. Regression Results: Dependent Variable: RGDPPC

\begin{tabular}{|c|c|c|c|c|c|c|}
\hline Variable & OLS & OLS & OLS & GMM & GMM & GMM \\
\hline & Model 1 & Model 2 & Model 3 & Model 4 & Model 5 & Model 6 \\
\hline \multirow{2}{*}{$\mathrm{C}$} & -482.0337 & -343.0652 & -116.5476 & -2400.519 & -1321.135 & -851.174 \\
\hline & -1.129771 & -0.968838 & -0.249137 & $(-3.004094)^{* * *}$ & $(-3.148513)^{* * *}$ & -1.566939 \\
\hline \multirow{2}{*}{ IIST } & 806.8443 & & & 2853.558 & & \\
\hline & $(2.114754)^{* *}$ & & & $(3.114908)^{* * *}$ & & \\
\hline \multirow{2}{*}{ Sii } & & 685.3715 & & & 1675.579 & \\
\hline & & $(2.536967)^{* *}$ & & & $(5.246994)^{* * *}$ & \\
\hline \multirow{2}{*}{$\mathrm{Ri}$} & & & 296.3029 & & & 196.6219 \\
\hline & & & 0.775096 & & & 0.47228 \\
\hline \multirow{2}{*}{ SAVGD } & 28.39167 & 29.95536 & 30.15453 & 37.27116 & 40.18182 & 17.07292 \\
\hline & $(2.562602)^{* *}$ & $(2.843858)^{* *}$ & $(2.46218)^{* *}$ & $(2.091764)^{*}$ & $(2.923394)^{* * *}$ & 1.292803 \\
\hline \multirow{2}{*}{ INFCPI } & -28.68049 & -22.73401 & -21.85992 & -71.26568 & -42.7683 & -23.85208 \\
\hline & $(-2.31649)^{* *}$ & $(-2.143448)^{* *}$ & -1.509949 & $(-3.492693)^{* * *}$ & $(-3.107275)^{* * *}$ & -1.287906 \\
\hline \multirow{2}{*}{ OPEN } & 83.46544 & 78.58621 & 77.57006 & 118.2423 & 93.81972 & 108.6565 \\
\hline & $(6.279713)^{* * *}$ & $(6.591241)^{* * *}$ & $(5.119038)^{* * *}$ & $(5.919254)^{* * *}$ & $(7.703166)^{* * *}$ & 5.665894 \\
\hline R-squared & 0.8307 & 0.844307 & 0.795464 & 0.667138 & 0.678589 & 0.661355 \\
\hline $\begin{array}{l}\text { Adjusted } \\
\text { R-sq. }\end{array}$ & 0.793078 & 0.809709 & 0.750011 & 0.588817 & 0.602963 & 0.581673 \\
\hline $\begin{array}{l}\text { S.E. of } \\
\text { regression }\end{array}$ & 152.5172 & 146.2597 & 167.6394 & 204.8789 & 201.3237 & 206.651 \\
\hline DW stat & 1.462563 & 1.678548 & 1.100245 & 1.999214 & 1.834138 & 1.21778 \\
\hline $\begin{array}{l}\text { Sum squared } \\
\text { resid }\end{array}$ & 418707.1 & 385054.2 & 505853.3 & 713581 & 689031.1 & 725978.5 \\
\hline J-statistic & & & & 0.052536 & 0.02859 & 0.082943 \\
\hline
\end{tabular}

First three models are tested on OLS. All variables have expected signs and are highly significant. Inflation measure having expected negative sign and significant suggests that unstable macro-economic conditions have a negative effect on economic growth. Hence pursuing policies of inflation financed growth might not be fruitful in long run. Coefficient of savings also remains positive in all three models and significant clearly showing saving is instrumental to growth as it increases capital accumulation and investments. The coefficient of openness represented by trade to GDP having expected positive sign and highly significant in all three models, showing increased trade liberalization impact growth in a positive way. In model 1, our main institutional variable is tested. Its coefficients are significant and positive indicate institutional quality positively and significantly influence growth. We also produce result of two sub-indices of index of index of institutionalized social technologies, namely risk reducing technologies in model 2 and anti-rent seeking technologies in model 3. All except anti-rent seeking index remains positive and significant. This show antirent seeking 
technologies although important, does not produce impact on growth alone, but when combined into aggregate index.

With some of the variables, there is an obvious endogeneity problem: previous research has shown, that, e.g., if saving increase, it will increase investment and leads to growth, hence it might be endogenous. The same is true for other variables. Endogeneity might even be a problem for our index. To encounter this problem these models are regressed based on GMM methodology. For this, First and Second lags of dependent variable and first lag of all independent variables are used as instruments. In model 4 to 6 , confirming the OLS results, the overall index of institutions and risk reducing index seems to significantly influence growth. There significant level also increased. The signs of other variable also remain same however they became even more significant. Overall the result remains unchanged.

Summing up, the overall index of institutionalized social technologies, have a significant (positive) influence on growth. The similar result witnessed in one of its sub index namely risk reducing technologies. However anti-rent seeking technologies remained insignificant.

These institutional indices are also comparable as they all have similar range between 0 and 1 . The highest coefficient on our main index clearly depict that both sub-indices alone cannot produce as much influence on growth as when they are combined.

\section{Conclusion}

Pakistan. All three measures of institutional quality significantly and positively affect growth. Moreover, our analysis indicates that between the two forms of institutions measured as a sub- indices of institutionalized social technologies, Risk reducing technologies impact growth considerable more than the Anti-rent seeking technologies. The other control variables show macroeconomic stability, savings and openness also have significant impact as predicted by theory. On policy front, developing county such as Pakistan or any other country for that matter must make and strengthen their instructions in order to achieve sustainable development. In its absence, even best policies for development and attracting investment might fail as no incentive can balance the huge business risk that could arise if property rights are not secured and contract enforcement is week. Also menses of corruption and nepotism divert any policy incentives given to entrepreneurs towards rent seekers making economy stuck in structural rigidities making any policy ineffective.

\section{References}

Acemoglu, D., Johnson, S., \& Robinson, J. A. (2001). The colonial origins of comparative development: An empirical investigation. American economic review, 91(5), 1369-1401. https://doi.org/10.1257/aer.91.5.1369

Acemoglu, D., Johnson, S., \& Robinson, J. A. (2005). Institutions as a fundamental cause of long-run growth. Handbook of economic growth, 1, 385-472.

Acemoglu, D., \& Verdier, T. (1998). Property rights, corruption and the allocation of talent: a general equilibrium approach. The economic journal, 108(450), 1381-1403. https://doi.org/10.1111/1468-0297.00347 
Acemoglu, D. (1995). Reward structures and the allocation of talent. European Economic Review, 39(1), 17-33. https://doi.org/10.1016/0014-2921(94)00014-Q

Ahmed, S. (2001). Poverty reduction and governance in South Asia. Mahbub ul Haq Human Development Review, 1(1), 34-60.

Barro, R. J. (1991). Economic growth in a cross section of countries. The quarterly journal of economics, 106(2), 407-443. https://doi.org/10.2307/2937943

Baumol, W. J. (1993). Entrepreneurship, Management, and the Structure of Payoffs. Cambridge, Mass, and London. In: The MIT Press.

Baumol, W. J. (1996). Entrepreneurship: Productive, unproductive, and destructive. Journal of business venturing, 11(1), 3-22. https://doi.org/10.1016/0883-9026(94)00014-X

Boserup, E. J. P., \& Review, D. (1996). Development theory: An analytical framework and selected application. 505-515. https://doi.org/10.2307/2137718

Carroll, C. D., \& Weil, D. N. (1994). Saving and growth: a reinterpretation. Paper presented at the Carnegie-Rochester conference series on public policy. https://doi.org/10.1016/0167-2231(94)90006-X

Coase, R. H. (1960). The problem of social cost. In Classic papers in natural resource economics, 87-137. Springer. https://doi.org/10.1057/9780230523210_6

Day, R. H., \& Walter, J. L. (1989). Economic growth in the very long run: On the multiple-phase interaction of population, technology, and social infrastructure. Economic complexity, chaos, sunspots, bubbles, and nonlinearity. Cambridge University Press, Cambridge, 253-89.

De Long, J. B., \& Shleifer, A. (1993). Princes and merchants: European city growth before the industrial revolution. The Journal of Law and Economics, 36(2), 671-702. https://doi.org/10.3386/w4274

De Soto, H., \& Taylor, J. (2011). The Mystery of Capital: Why Capitalism Triumphs in the West and Fails Everywhere Else. Crane Library at the University of British Columbia.

Easterly, W. (2003). The political economy of growth without development. In search of prosperity: Analytic narratives on economic growth, 439-469.

Fernandes, A., Kraay, C. J. S. A. G., \& Bank, R. I. T. W. (2007). Property rights institutions, contracting institutions and growth in South Asia: Macro and Micro Evidence.

Frye, T., \& Shleifer, A. (1996). The invisible hand and the grabbing hand.

Grier, K. B., \& Tullock, G. (1989). An empirical analysis of cross-national economic growth, 1951-1980. Journal of monetary economics, 24(2), 259-276. https://doi.org/10.1016/0304-3932(89)90006-8

Grossman, S. J., \& Hart, O. D. (1986). The costs and benefits of ownership: A theory of vertical and lateral integration. Journal of political economy, 94(4), 691-719. 
https://doi.org/10.1086/261404

Gwartney, J., Holcombe, R., \& Lawson, R. (1998). The scope of government and the wealth of nations. Cato J., 18, 163.

Gwartney, J., Lawson, R., \& Norton, S. (2008). Economic freedom of the world: 2008 annual report. The Fraser Institute.

Gwartney, J. D., \& Lawson, R. (2001). Economic freedom of the world 2001 annual report. The Fraser Institute.

Hall, R. E., \& Jones, C. I. (1999). Why do some countries produce so much more output per worker than others?. The quarterly journal of economics, 114(1), 83-116.

Hansen, L. P., \& Singleton, K. J. (1982). Generalized instrumental variables estimation of nonlinear rational expectations models. Econometrica: Journal of the Econometric Society, 1269-1286. https://doi.org/10.2307/1911873

Hart, O. (1995). Firms, contracts, and financial structure. Clarendon Press. https://doi.org/10.1093/0198288816.001.0001

Hart, O., \& Moore, J. (1990). Property Rights and the Nature of the Firm. Journal of political economy, 98(6), 1119-1158. https://doi.org/10.1086/261729

Heston, A., Summers, R., Aten, B. J. E. D., \& Change, C. (2009). Penn World Table Version 6.3. Centre for international comparisons of production, income and prices, University of Pennsylvania.

Horwich, G. (2000). Economic lessons of the Kobe earthquake. Economic development and cultural change, 48(3), 521-542.

Ismail, Z. H., Rizvi, S., \& Mahmood, A. (2000). Governance, Decentralisation, and Poverty: The Case of Pakistan [with Comments]. The Pakistan Development Review, 1013-1030. https://doi.org/10.30541/v39i4IIpp.1013-1030

Jalilian, H., Kirkpatrick, C., \& Parker, D. (2007). The impact of regulation on economic growth in developing countries: A cross-country analysis. World development, 35(1), 87-103. https://doi.org/10.1016/j.worlddev.2006.09.005

Javorcik, B. S., \& Wei, S.-J. (2000). Corruption and composition of foreign direct investment: firm-level evidence.

Jin, J. C. (2000). Openness and growth: an interpretation of empirical evidence from East Asian countries. Journal of International Trade \& Economic Development, 9(1), 5-17. https://doi.org/10.1080/096381900362517

Johnson, S., Kaufmann, D., \& Zoido-Lobaton, P. (1998). Regulatory discretion and the unofficial economy. The American Economic Review, 88(2), 387-392.

Johnson, S., McMillan, J., \& Woodruff, C. (2000). Entrepreneurs and the ordering of institutional reform: Poland, Slovakia, Romania, Russia and Ukraine compared. Economics of 
Transition, 8(1), 1-36. https://doi.org/10.1111/1468-0351.00034

Jones, E. (2003). The European miracle: environments, economies and geopolitics in the history of Europe and Asia. Cambridge University Press. https://doi.org/10.1017/CBO9780511817700

Kaufman, D., Kraay, A., \& Mastruzzi, M. (2005). Governance Matters IV: Governance Indicators for 1996-2004. World Bank, May. In.

Kirkpatrick, C., Parker, D., \& Zhang, Y. F. (2006). Foreign direct investment in infrastructure in developing countries: does regulation make a difference?. Transnational corporations, 15(1), 143-172.

Kormendi, R. C., \& Meguire, P. G. (1985). Macroeconomic determinants of growth: cross-country evidence. Journal of Monetary economics, 16(2), 141-163. https://doi.org/10.1016/0304-3932(85)90027-3

Lane, J.-E. (1984). Olson Mancur, The Rise and Decline of Nations, New Haven: Yale University Press, 1982, 4(3), 268-271. https://doi.org/10.1017/S0143814X00002270

Levine, R., \& Renelt, D. (1992). A sensitivity analysis of cross-country growth regressions. The American economic review, 942-963.

Maddison, A. (1992). A long-run perspective on saving. The Scandinavian Journal of Economics, 181-196. https://doi.org/10.2307/3440445

Magee, S. P., Brock, W. A., \& Young, L. (1989). Black hole tariffs and endogenous policy theory: Political economy in general equilibrium. Cambridge University Press.

Mahbub-ul-Haque, K. (1999). Human Development in South Asia: The Crises of Governance. In: Oxford University Press, Karachi.

Mankiw, N. G., Romer, D., \& Weil, D. N. (1992). A contribution to the empirics of economic growth. The quarterly journal of economics, 107(2), 407-437. https://doi.org/10.2307/2118477

Manly, B. J. C., \& Hall, L. (1994). A primer of multivariate statistics.

Mehlum, H., Moene, K., \& Torvik, R. (2003). Destructive creativity. Nordic Journal of Political Economy, 29(1), 77-83.

Méon, P. G., \& Sekkat, K. (2004). Does the quality of institutions limit the MENA's integration in the world economy?. World Economy, 27(9), 1475-1498.

Miller, T., Kim, A. B., \& Holmes, K. J. (2015). 2015 Index of economic Freedom.

Modigliani, F. (1990). Recent developments in saving rates: a life cycle perspective. Paper presented at the Frisch Lecture delivered at the 6th World Congress of the Econometric Society, September, Barcelona.

Modigliani, F. (1970). The life cycle hypothesis of saving and intercountry differences in the 
saving ratio. Induction, growth and trade, 197-225.

Murphy, K. M., Shleifer, A., \& Vishny, R. W. (1991). The allocation of talent: Implications for growth. The quarterly journal of economics, 106(2), 503-530. https://doi.org/10.2307/2937945

Nelson, R. (2007). Institutions, "Social technologies", and economic progress. The Global Network for Economics of Learning, Innovation, and Competence Building System (GLOBELICS). Working Papers Series, (2007-03).

Nelson, R. R., \& Sampat, B. N. (2001). Making sense of institutions as a factor shaping economic performance. Revista de Economía Institucional, 3(5), 17-51. https://doi.org/10.1016/S0167-2681(00)00152-9

Nicoletti, G., Scarpetta, S., \& Boylaud, O. (1999). Summary indicators of product market regulation with an extension to employment protection legislation.

North, D. C. (1981). Structure and change in economic history. Norton.

North, D. C., \& Thomas, R. P. (1973). The rise of the western world: A new economic history. Cambridge University Press. https://doi.org/10.1017/CBO9780511819438

North, D. C., \& Wallis, J. J. (1994). Integrating institutional change and technical change in economic history a transaction cost approach. Journal of Institutional and Theoretical Economics (JITE)/Zeitschrift für die gesamte Staatswissenschaft, 150(4), 609-624.

North, D. C. (1991). Institutions. Journal of economic perspectives, 5(1), 97-112. https://doi.org/10.1257/jep.5.1.97

Olson, M. (2000). Power and prosperity: Outgrowing communist and capitalist dictatorships. Basic Books.

Olson, M., Sarna, N., \& Swamy, A. V. (2000). Governance and growth: A simple hypothesis explaining cross-country differences in productivity growth. Public Choice, 102(3-4), 341-364.

Pearson, K. (1894). Contributions to the mathematical theory of evolution. Philosophical Transactions of the Royal Society of London. A, 185, 71-110.

Pelikan, P. (2003). Bringing institutions into evolutionary economics: another view with links to changes in physical and social technologies. Journal of Evolutionary Economics, 13(3), 237-258. https://doi.org/10.1007/s00191-003-0157-9

Putnam, R. D., Leonardi, R., \& Nanetti, R. Y. (1994). Making democracy work: Civic traditions in modern Italy. Princeton university press.

Ramakrishna, G. (2002). The effect of trade liberalization on economic growth: the case of Ethiopia. Finance India, 16(4), 1295.

Reiersøl, O. (1941). Confluence analysis by means of lag moments and other methods of confluence analysis. Econometrica: Journal of the Econometric Society, 1-24. 
https://doi.org/10.2307/1907171

Reisen, H., \& Soto, M. (2001). Which types of capital inflows foster developing-country growth?. International finance, 4(1), 1-14.

Rodrik, D., Subramanian, A., \& Trebbi, F. (2004). Institutions rule: the primacy of institutions over geography and integration in economic development. Journal of economic growth, 9(2), 131-165. https://doi.org/10.1023/B:JOEG.0000031425.72248.85

Romer, P. M. (1989). Human capital and growth: theory and evidence.

Sargan, J. D. (1958). The estimation of economic relationships using instrumental variables. Econometrica: Journal of the Econometric Society, 393-415. https://doi.org/10.2307/1907619

Shafique, S., Haq, R., \& Arif, G. M. (2006). Governance and Income Inequality [with Comments]. The Pakistan Development Review, 751-760.

Shleifer, A., \& Vishney, R. J. M. W. (1993). Corruption'Quarterly Journal of Economics, 108, 599-617. 39.

Solow, R. M. (1956). A contribution to the theory of economic growth. The quarterly journal of economics, 70(1), 65-94. https://doi.org/10.2307/1884513

Tabellini, G. (2010). Culture and institutions: economic development in the regions of Europe. Journal of the European Economic association, 8(4), 677-716. https://doi.org/10.1111/j.1542-4774.2010.tb00537.x

Tollison, R. J. D. M., Cambridge. (1997). Rent seeking.\| in-Perspectives on public choice.\| ed.

Usher, D. (1987). Theft as a paradigm for departures from efficiency. Oxford Economic Papers, 39(2), 235-252. https://doi.org/10.1093/oxfordjournals.oep.a041783

Williamson, O. (1985). 1985 The economic institutions of capitalism. New York: Free Press.

\section{Notes}

Note 1. For detail survey of varied meanings of institutions in political science, see Hall and Taylor (1994) or Powell and DiMaggio (1991) for sociological perspective.

\section{Copyright Disclaimer}

Copyright for this article is retained by the author(s), with first publication rights granted to the journal.

This is an open-access article distributed under the terms and conditions of the Creative Commons Attribution license (http://creativecommons.org/licenses/by/3.0/). 